\title{
Role of interleukin 1 in the regulation of cyclooxygenase gene expression in rat endometrial stromal cells
}

\author{
B. M. Bany ${ }^{1 *}$ and T. G. Kennedy $y^{1,2+}$ \\ Departments of ${ }^{1}$ Physiology and ${ }^{2}$ Obstetrics and Gynaecology, \\ The University of Western Ontario, London, Ontario, N6A 5C1, Canada
}

\begin{abstract}
Interleukin $1 \alpha(\mathrm{IL}-1 \alpha)$ stimulates prostaglandin production and cyclooxygenase activity in endometrial stromal cells isolated from the uteri of ovariectomized rats that have been sensitized for the decidual cell reaction. The aim of the present study was to examine the effect of IL- $1 \alpha$ on the amount of cyclooxygenase mRNA and protein in these cells. Treatment with IL-1 $\alpha\left(20 \mathrm{ng} \mathrm{ml}^{-1}\right)$ for $24 \mathrm{~h}$ significantly increased steadystate concentrations of cyclooxygenase $2(\mathrm{COX}-2) \mathrm{mRNA}$ and protein in the cells, as determined by northern and western blot analyses, respectively. Cyclooxygenase 1 $(C O X-1)$ mRNA and protein were not detected. Dexamethasone $\left(5 \mu \mathrm{mol} \mathrm{l}^{-1}\right)$ prevented the IL-1 $\alpha$-induced increase in COX-2 steady-state mRNA. Immunocytochemical staining of COX-2 in the treated cells indicated that IL-1 $\alpha$ increased staining, while dexamethasone inhibited this increase. Furthermore, the changes in staining were generalized and not confined to a small subpopulation of cells. These data demonstrate that IL- $1 \alpha$ increases steady-state concentrations of COX-2 mRNA and protein in endometrial stromal cells isolated from the uteri of rats that have been sensitized for decidualization.
\end{abstract}

\section{Introduction}

Cyclooxygenase is a rate-limiting enzyme in the production of biologically active prostaglandins and thromboxanes (DeWitt, 1991; Smith et al., 1991). Since cyclooxygenase is a suicide enzyme (Egan et al., 1976) and must be replaced to sustain prostaglandin production, modulation of cyclooxygenase gene expression may have a role in agonistinduced increases in prostaglandin production. Indeed, agonist-induced increases in prostaglandin production are accompanied by an increase in cyclooxygenase gene expression in several cell types (DeWitt, 1991; Herschman, 1994). Two isozymes of cyclooxygenase have been identified, COX-1 and COX-2. Genes for both COX-1 and COX-2 have been fully cloned in a number of mammalian species, including humans (Hla and Neilson, 1992; Takahashi et al., 1992), mice (DeWitt et al., 1991; Kujubu et al., 1991; O'Banion et al., 1992), rats (Feng et al., 1993) and sheep (Merlie et al., 1988; Zhang et al., 1996). In most species, the COX-2 mRNA is much larger than the COX-1 mRNA $(\sim 4.1 \mathrm{~kb}$ versus $\sim 2.8 \mathrm{~kb})$, mainly because of the presence of a large 3 -untranslated region in COX-2 which contains a large number of Shaw-Kamen sequences that are known to confer selective mRNA degradation on other transcripts (Shaw and Kamen, 1986). Despite the differences in transcript size, the COX-1

*Present address: Department of Medical Biochemistry, University of Calgary, Calgary, Alberta, Canada.

${ }^{+}$Correspondence.

Received 20 April 1998 and COX-2 genes encode proteins of almost identical molecular mass that are approximately $75 \%$ homologous within species.

Endometrial prostaglandins, particularly of the E-series, play an important role in blastocyst implantation and decidualization in many animals (reviewed by Kennedy, 1990; Smith, 1991). Although prostaglandins are essential for implantation, the source and control of their biosynthesis in the endometrium during implantation are not known. However, luminal epithelial cells may release signals in response to the implanting blastocyst which, in turn, stimulate prostaglandin production by endometrial stromal cells. The observation that IL-1 produced by mouse luminal epithelial cells can stimulate prostaglandin production by cultured endometrial stromal cells is consistent with this scheme (Jacobs and Carson, 1993). IL-1 bioactivity can be detected in the mouse uterus during the peri-implantation period and this is accompanied by an increase in uterine IL$1 \alpha$ and IL-1 $\beta$ mRNA (De et al., 1993). Application of a deciduogenic stimulus on day 4 of pseudopregnancy results in an increase in IL-1 $\alpha$ and IL-1 $\beta$ mRNA in the uterine horn undergoing decidualization compared with the nonstimulated uterine horn (Choudhuri and Wood, 1993). Therefore, IL-1 receptor ligands may have a role in controlling prostaglandin production in endometrial stromal cells during implantation.

IL-1 $\alpha$ stimulates prostaglandin production by endometrial stromal cells isolated from rat uteri sensitized for the decidual cell reaction (Bany and Kennedy, 1995a). 
This increase in prostaglandin production is accompanied by a transcription- and translation-dependent increase in cyclooxygenase activity. The objective of the present study was to determine the effect of IL- $1 \alpha$ on the expression of COX-1 and COX-2 genes in cultured rat endometrial stromal cells isolated from uteri sensitized for decidualization.

\section{Materials and Methods}

\section{Animals}

Female Harlan Sprague-Dawley rats (200-225 g), obtained from Harlan Sprague-Dawley Inc. (Indianapolis, IN), were housed under conditions of controlled temperature and photoperiod ( $14 \mathrm{~h}$ light:10 $\mathrm{h}$ dark; $12: 00 \mathrm{~h}$ as the midpoint of the light phase) with free access to food and water. The animals were ovariectomized under ether anaesthesia and allowed at least 6 days to recover. Oestradiol and progesterone in sesame oil (Sigma Chemical Company, St Louis, MO) were administered s.c. as described by Bany and Kennedy (1995b) to obtain rats with uteri sensitized for decidualization.

\section{Endometrial stromal cell isolation and culture}

Rats were killed by decapitation and the endometrial stromal cells were isolated by a modification of the method of McCormack and Glasser (1980) as described by Bany and Kennedy $(1995 a, b)$. The stromal cells were suspended in Dulbecco's modified Eagle's medium: F12 nutrient mixture (DMEM:F12) containing 10\% (v/v) heat-inactivated charcoalstripped fetal calf serum, $50 \mathrm{iu}$ penicillin $\mathrm{ml}^{-1}, 50 \mu \mathrm{g}$ streptomycin $\mathrm{ml}^{-1}$ and $1.25 \mu \mathrm{g}$ fungizone $\mathrm{ml}^{-1}$ (GIBCO-BRL, Burlington, Ontario). The cell suspension was filtered through nylon mesh $(70 \mu \mathrm{m})$ to remove glands and clumps of epithelial cells, and plated at $5 \times 10^{5}$ cells (in $0.5 \mathrm{ml}$ culture medium) in 24-well plates (Becton-Dickinson, Lincoln Park, NJ) with or without Thermanox ${ }^{\boxplus}$ coverslips (Nunc Inc., Naperville, IL). After an initial incubation period of $2 \mathrm{~h}$ at $37^{\circ} \mathrm{C}$ under $5 \% \mathrm{CO}_{2}$ and $95 \%$ air to allow differential attachment of the stromal cells, the medium and free floating cells were removed and replaced with serum-free DMEM:F12. This was defined as $0 \mathrm{~h}$ of day 1 of culture. The cultures were free of epithelial cells as indicated by the absence of positively staining cells for cytokeratin by immunocytochemical analysis (data not shown).

Cells were treated with or without human recombinant IL-1 $\alpha$ for $24 \mathrm{~h}$ in serum-free DMEM:F12. Previous studies have shown that the stimulatory effect of IL- $1 \alpha$ on prostaglandin $\mathrm{E}_{2}\left(\mathrm{PGE}_{2}\right)$ accumulation is greatest when it is added to the culture medium for $24 \mathrm{~h}$ on day 2 of culture (Bany and Kennedy, 1995a). Therefore, the experiments were carried out on day 2. Dexamethasone (Sigma, St Louis, MO), prepared as a stock at a concentration of $10 \mathrm{mmol} \mathrm{l}^{-1}$ in ethanol, was used in some experiments. Since a final concentration of $5 \mu \mathrm{mol}$ dexamethasone $\mathrm{l}^{-1}$ was used, all treatments contained $0.05 \%$ ethanol in experiments involving dexamethasone.

\section{Northern blot analysis}

Total RNA was isolated from the cells using a single-step guanidine thiocyanate procedure (Chomczynski and Sacchi, 1987). Total RNA was quantified by absorbance at $260 \mathrm{~nm}$ as well as by ethidium bromide staining after electrophoresis through agarose gels. Samples of total RNA (10 $\mu$ g per lane) were denatured in $6 \%(\mathrm{v} / \mathrm{v})$ formaldehyde and $50 \%(\mathrm{v} / \mathrm{v})$ formamide in 4-morpholinepropanesulphonic acid (MOPS) buffer (10 mmol MOPS $\mathrm{I}^{-1}, 5 \mathrm{mmol}$ sodium acetate $\mathrm{l}^{-1}, 1 \mathrm{mmol}$ EDTA $\mathrm{I}^{-1}, \mathrm{pH} \mathrm{7.2)}$ at $65^{\circ} \mathrm{C}$ for $15 \mathrm{~min}$, subjected to denaturing agarose gel $(1.1 \%)$ electrophoresis and were then transferred to Hybond-N membranes (Amersham, Oakville, $\mathrm{ON}$ ) by capillary transfer as described by Sambrook et al. (1989). The RNA was crosslinked to the membranes by UV irradiation $\left(0.12 \mathrm{~J} \mathrm{~cm}^{-2}\right)$.

Probes for COX-1 and COX-2 were prepared from EcoRI digests of full-length rat cDNAs (Feng et al., 1993). An 18S rRNA probe (Smith and Hammond, 1991) was also used to determine the relative amount of RNA loaded into each lane and transferred to the membranes. The COX-1, COX-2 and $18 \mathrm{~S}$ rRNA probes $(25 \mathrm{ng}$ ) were labelled using a random primer DNA labelling system (GIBCO-BRL) in the presence of [ $\left.{ }^{32} \mathrm{P}\right]-$ deoxycytidine $5^{\prime}$-triphosphate (dCTP) (Amersham, Oakville, $\mathrm{ON}$ ) and purified using nick columns (Pharmacia Biotech, Baie d'Urfé, PQ) according to the manufacturer's instructions. Prehybridization, hybridization and washing were carried out as described by Bany and Kennedy (1997). The membranes were then subjected to autoradiography at $-70^{\circ} \mathrm{C}$ with intensifying screens. Membranes were de-probed between hybridizations in stripping buffer $\left(1 \mathrm{mmol}\right.$ Tris $\mathrm{l}^{-1}$, 1 mmol EDTA $~^{-1}, 0.1$ strength Denhardts' reagent (Sambrook et al., 1989), $\mathrm{pH} 8.0$ ) for $2 \mathrm{~h}$ at $75^{\circ} \mathrm{C}$. The relative intensities of the mRNA signals on the autoradiograms were quantified by densitometry and the results are expressed as the ratio of mRNA signal:18S rRNA signal.

\section{Western blot analysis}

Cells were washed with PBS, scraped into boiling lysis buffer ( $1 \%(\mathrm{w} / \mathrm{v})$ SDS, $10 \mathrm{mmol}^{\text {Tris }} \mathrm{l}^{-1}$, $\left.\mathrm{pH} 7.4\right)$ and boiled for $5 \mathrm{~min}$. After centrifugation at $12000 \mathrm{~g}$ for $5 \mathrm{~min}$ to remove insoluble material, protein concentrations in the samples were determined using the Bio-Rad DC protein assay (Bio-Rad Laboratories, Mississauga, ON). Protein samples (50 $\mu \mathrm{g})$ and prestained rainbow molecular mass markers (Amersham, Oakville, ON) were subjected to $10 \%(\mathrm{w} / \mathrm{v})$ SDS-PAGE under reducing conditions (Laemmli, 1970), and then transferred to Immobilon ${ }^{\text {TM }}-\mathrm{P}$ membranes (Millipore Corporation, Bedford, MA) by electroblotting (Towbin et al., 1979). COX-1 and COX-2 immunoreactivity was detected on the membranes by chemiluminescence as described by Bany and Kennedy (1997). Densitometry was carried out to determine changes in the concentration of COX-1 and COX-2 proteins.

\section{Immunocytochemistry}

Cells grown on coverslips were rinsed in PBS (pH 7.4), fixed in ice-cold methanol for $5 \mathrm{~min}$, air dried, and then 
rehydrated in PBS. COX-1 or COX-2 immunoreactivity was detected in the cells by immunocytochemistry as described by Bany and Kennedy (1997). Special care was taken to ensure that all coverslips were incubated with the peroxidase substrate for exactly $5 \mathrm{~min}$. Some of the coverslips were incubated with primary antibody preincubated for $2 \mathrm{~h}$ at room temperature with a tenfold excess by weight of control peptide (the peptide used to generate the antibodies that were used) to determine the specificity of the immunolocalization for each antibody.

\section{Statistical analysis}

Analysis of variance (ANOVA) was used to determine treatment effects. In cases in which significant $(P<0.05)$ interactions were detected, Duncan's multiple range test was used for group comparisons. All statistical analysis was carried out using SAS Statistical Software (SAS, Cory, NC).

\section{Results}

\section{Effect of IL-1 $\alpha$ on COX-1 and COX-2 gene expression}

Northern blot analyses were used to determine the effects of IL-1 $\alpha$ on the amount of COX-1 and COX-2 mRNA in the cultured cells. Cells were incubated with or without IL-1 $\alpha$ $\left(20 \mathrm{ng} \mathrm{ml}^{-1}\right)$ for $24 \mathrm{~h}$ on day 2 of culture and the steadystate concentrations of COX-1 and COX-2 mRNA were determined. COX-2 mRNA was detected on the blots (Fig. 1a); COX-1 mRNA was not detected. Furthermore, after incubation with IL- $1 \alpha$, the relative abundance of $\mathrm{COX}-2$ mRNA, as assessed by the ratio of mRNA signal:18 $\mathrm{S}$ rRNA signal, increased significantly $(P<0.01)$ by approximately sevenfold (Fig. 1b).

Western blot analyses were used to determine the effect of IL- $1 \alpha$ on the amount of COX-1 and COX-2 proteins in the cultured cells. Cells were incubated with or without IL-1 $\alpha$ $\left(20 \mathrm{ng} \mathrm{ml}^{-1}\right)$ for $24 \mathrm{~h}$ on day 2 of culture and the amount of immunoreactive COX-1 and COX-2 protein was determined. COX-2 protein with an approximate molecular mass of $68 \mathrm{kDa}$ was immunodetected (Fig. 2a); COX-1 protein was not detected. Immunodetectable COX-2 protein was present in the cells incubated with vehicle alone and the concentration increased after incubation with IL-1 $\alpha$, as indicated by a significant $(P<0.05)$ increase in band density (Fig. $2 b$ ). Blots incubated with COX-2 primary antibodies preincubated with control peptide did not show any bands (data not shown).

\section{Effect of dexamethasone on the $I L-1 \alpha$-induced increase in COX-2 gene expression}

Since dexamethasone inhibits or greatly reduces IL- $1 \alpha$ induced increases in $\mathrm{PGE}_{2}$ accumulation and cyclooxygenase activity in rat endometrial stromal cells (Bany and Kennedy, 1995a), the effect of dexamethasone on IL- $1 \alpha$-induced increases in COX-2 mRNA and protein was determined. (a)
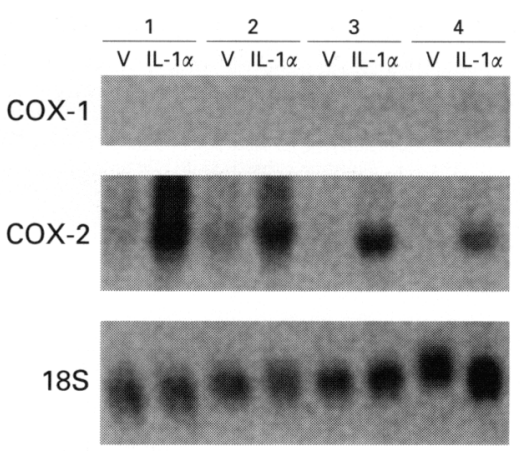

(b)

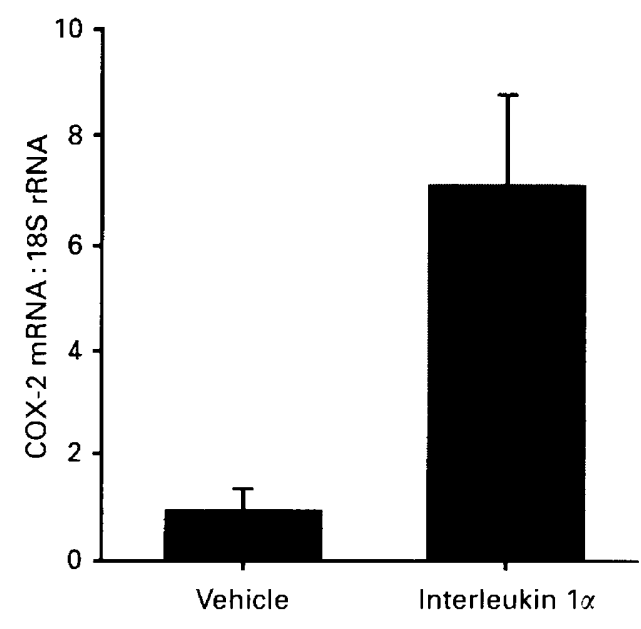

Fig. 1. Northern blot analysis of cyclooxygenase 1 (COX-1) and cyclooxygenase 2 (COX-2) mRNA from rat endometrial stromal cells cultured with vehicle (V) or interleukin $1 \alpha(\mathrm{IL}-1 \alpha)\left(20 \mathrm{ng} \mathrm{ml}^{-1}\right)$ for $24 \mathrm{~h}$ on day 2 of culture. (a) Autoradiograph of a membrane containing samples from four separate experiments $(1-4)$. The membrane was hybridized with ${ }^{32} \mathrm{P}-$ labelled COX-1, COX-2 and $18 \mathrm{~S}$ rRNA cDNA probes. (b) Mean $( \pm \mathrm{SEM}, n=4)$ ratio of COX-2 mRNA:18S rRNA signals, as determined by image analysis with the ratio for the vehicle-treated cells set to 1 .

Cells were incubated with or without IL-1 $\alpha\left(20 \mathrm{ng} \mathrm{ml}^{-1}\right)$ in the presence or absence of dexamethasone $\left(5 \mathrm{mmol} \mathrm{l}^{-1}\right)$ for $24 \mathrm{~h}$ on day 2 of culture and the steady-state concentration of COX-2 mRNA was determined (Fig. 3a). For the ratios of signal intensities of COX-2 mRNA and 185 rRNA (Fig. 3b), ANOVA revealed a significant $(P<0.0001)$ interaction between the effects of IL- $1 \alpha$ and dexamethasone. IL- $1 \alpha$ increased this ratio, but the increase was prevented when dexamethasone was present. The concentration of COX-2 in cells treated with vehicle, dexamethasone or IL-1 $\alpha$ and dexamethasone was not significantly different $(P>0.05)$. Probing these northern blots for COX-1 mRNA did not result in any detectable signals (data not shown).

The effect of dexamethasone on the amount of immunoreactive COX-2 protein was also investigated. COX2 protein was not detectable by western blot analyses in cells treated with dexamethasone or dexamethasone and IL- $1 \alpha$ (data not shown). 

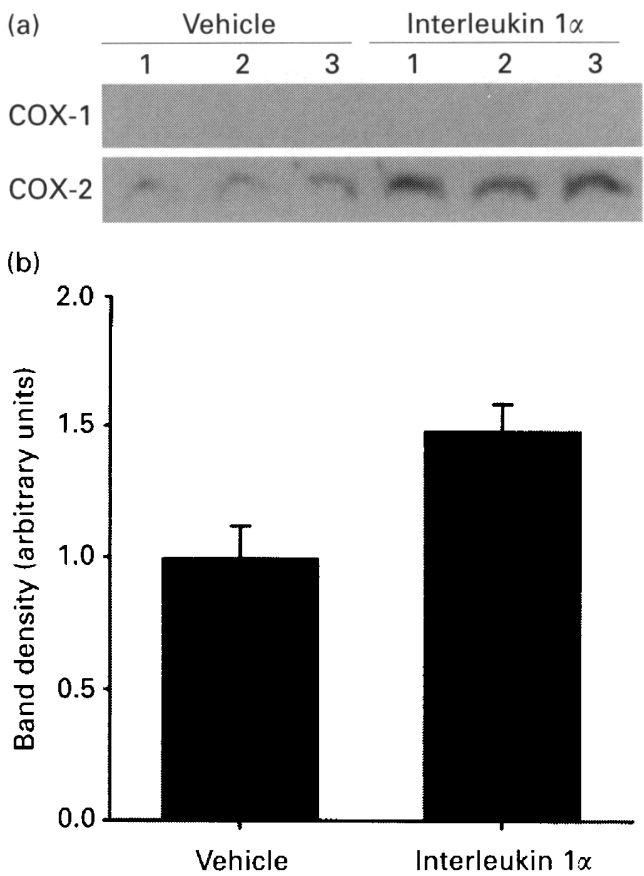

Fig. 2. Western blot analysis of cyclooxygenase 1 (COX-1) and cyclooxygenase 2 (COX-2) proteins in rat endometrial stromal cells cultured with vehicle or interleukin $1 \alpha\left(20 \mathrm{ng} \mathrm{m}^{-1}\right)$ for $24 \mathrm{~h}$ on day 2 of culture. (a) Results from two membranes containing samples (50 $\mathrm{ug}$ total protein per lane) from three separate experiments (1-3). One membrane was incubated with COX-1 antibody and the other was incubated with COX-2 antibody. (b) Mean ( \pm SEM, $n=3$ ) density of immunoreactive COX-2 protein signals, as determined by image analysis with the ratio for the vehicle-treated cells set to 1 .

\section{COX-1 and COX-2 immunocytochemistry}

Cells grown on coverslips were incubated with or without IL-1 $\alpha\left(20 \mathrm{ng} \mathrm{ml}^{-1}\right)$ in the presence or absence of dexamethasone $\left(5 \mu \mathrm{mol} \mathrm{l}^{-1}\right)$ for $24 \mathrm{~h}$ on day 2 of culture. Immunocytochemistry was performed on the cells to determine possible qualitative effects of IL- $1 \alpha$ and dexamethasone on COX-2 immunostaining. For all treatments, COX-2 staining was found in all cells (Fig. 4a-d). After incubation with IL- $1 \alpha$, the amount of staining in all cells appeared to increase for COX-2 (Fig. 4b) compared with vehicle-treated cells (Fig. 4a). In the presence of dexamethasone, IL-1 $\alpha$ did not cause an increase in staining for COX-2 (Fig. 4c,d). Pre-incubation of the COX-2 antibody with control peptide at a tenfold excess by weight caused a marked reduction in staining (Fig. 4e).

\section{Discussion}

This study shows that IL- $1 \alpha$ increases steady-state concentrations of COX-2 mRNA and protein in rat endometrial stromal cells isolated from uteri that have been sensitized for the decidual cell reaction. The effect on COX-2 protein concentration paralleled an increase in immunocytochemical staining in most cells, showing that the increase in COX-2 protein was generalized and did not (a)

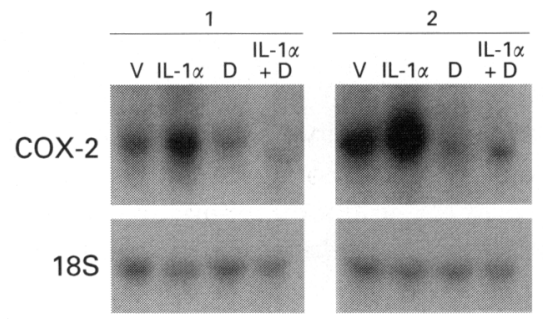

(b)

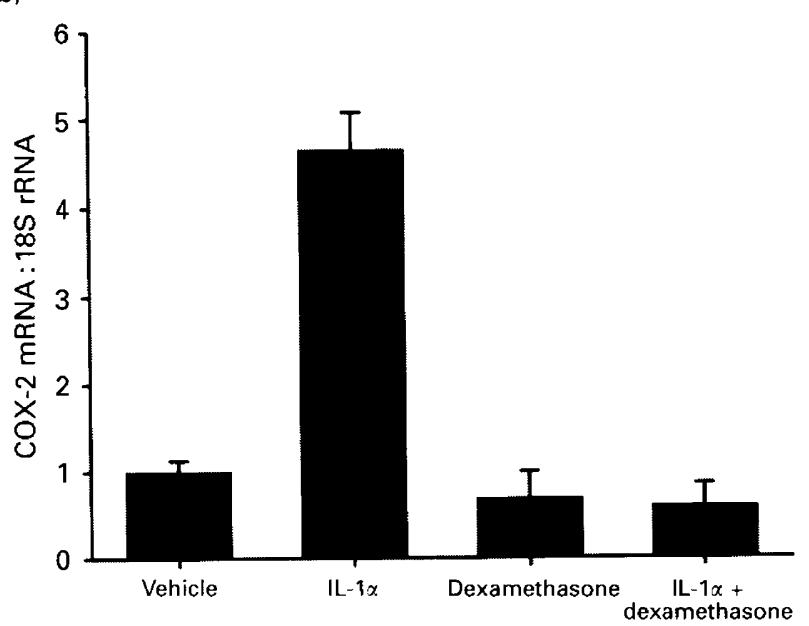

Fig. 3. Northern blot analysis of the effect of dexamethasone on interleukin $1 \alpha$ (IL- $1 \alpha)$-induced increase in steady-state cyclooxygenase 2 (COX-2) mRNA in rat endometrial stromal cells. Cells were incubated with vehicle (V), IL-1 $\alpha\left(20 \mathrm{ng} \mathrm{ml}^{-1}\right)$, dexamethasone (D) $\left(5 \mu \mathrm{mol} \mathrm{l}^{-1}\right)$ or IL-1 $\alpha$ and dexamethasone for $24 \mathrm{~h}$ on day 2 of culture. (a) Representative autoradiographs of membranes containing samples from two separate cultures (1 and 2). (b) Mean $( \pm$ SEM, $n=5$ ) ratio of mRNA:18S rRNA signals, as determined by image analysis with the ratio for the vehicle-treated cells set to 1 .

occur in a small subpopulation of stromal cells. It has been shown that IL- $1 \alpha$ causes transcription- and translationdependent increases in both prostaglandin production and cyclooxygenase activity in endometrial stromal cells isolated from rat uteri that have been sensitized for decidualization (Bany and Kennedy, 1995a). The present study suggests that these IL-1 $\alpha$-induced increases in prostaglandin production and cyclooxygenase activity are due, at least in part, to an increase in COX-2 gene expression. IL- $1 \alpha$ may also increase mRNA and protein stability of COX-2. Further studies are required to determine whether IL-1 $\alpha$ has such effects. IL-1 causes specific increases in the expression of the COX-2 gene in several non-uterine cell types (Kujubu et al., 1991; Rzymkiewicz et al., 1994; Kennard et al., 1995; Yucel-Lindberg et al., 1995; Porreca et al., 1996; Vigano et al., 1997) and mouse endometrial stromal cells (Jacobs and Carson, 1993; Jacobs et al., 1994).

In the present study, there was a discrepancy between the extent to which IL-1 $\alpha$ increased steady-state concentrations of COX-2 mRNA and protein in the cells. Whereas IL- $1 \alpha$ increased steady-state COX-2 mRNA by approximately sevenfold and cyclooxygenase activity by approximately sixfold (Bany and Kennedy, 1995a), the concentration of COX-2 protein increased by only $50 \%$. The reason for these 

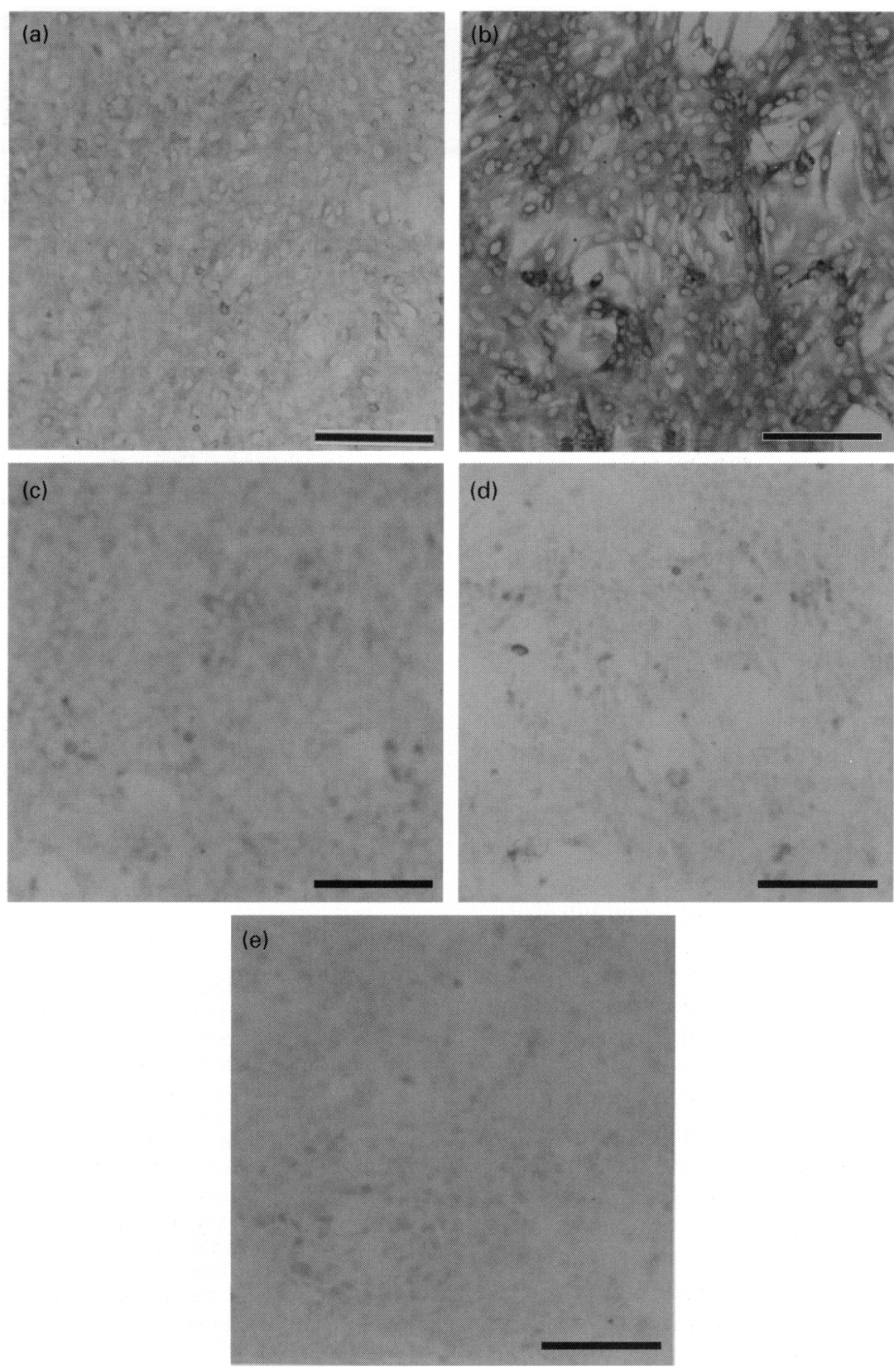

Fig. 4. Photomicrographs of rat endometrial stromal cells immunocytochemically stained with an antibody against cyclooxygenase 2. Cells were incubated with (a) vehicle, (b) interleukin $1 \alpha(\mathrm{IL}-1 \alpha)\left(20 \mathrm{ng} \mathrm{ml}^{-1}\right)$, (c) dexamethasone $\left(5 \mu \mathrm{mol} 1^{1}\right)$, or (d) IL-1 $\alpha$ and dexamethasone, for $24 \mathrm{~h}$ on day 2 of culture. Preincubation with control peptide (e) resulted in a marked reduction in staining. Scale bars represent $48 \mu \mathrm{m}$.

differences is unknown, but may be related to the fact that cyclooxygenase is a suicide enzyme (Egan et al., 1976). It is possible that inactivated COX-2 is not detected by western blot analysis, leading to a smaller increase in detectable COX-2 protein compared with COX-2 mRNA.

Dexamethasone, a synthetic glucocorticoid, decreases prostaglandin production and cyclooxygenase activity in rat endometrial stromal cells in the presence or absence of IL- $1 \alpha$ (Bany and Kennedy, 1995a). In the present study, dexamethasone decreased steady-state concentrations of
COX-2 mRNA and protein in the presence or absence of IL-1 $\alpha$. This suggests that the effects of dexamethasone on prostaglandin production and cyclooxygenase activity were due, at least in part, to inhibition of COX-2 gene expression. As shown in other cell types, glucocorticoids generally decrease COX-2 and not COX-1 gene expression (O'Banion et al., 1992). However, since COX-1 mRNA and protein were not detected by the methods used in this study, dexamethasone may also have an effect on COX-1 expression in rat endometrial stromal cells. 
COX-1 and COX-2 are expressed in a time- and cellspecific manner in the mouse endometrium during implantation. COX-2 mRNA and protein increase in the endometrial stromal cells undergoing decidualization in the subepithelial region just after the onset of implantation (Jacobs et al., 1994; Chakraborty et al., 1996). Approximately 3.5 days after implantation, COX-1 mRNA and protein also appear in the endometrial stromal cells undergoing decidualization (Chakraborty et al., 1996). COX-1 gene expression is not required for implantation in mice since COX-1-deficient female mice are fertile (Langenbach et al., 1995). In contrast, Lim et al. (1997) showed that COX-2deficient mice are defective in implantation and decidualization due to uterine-specific deficiencies. In addition, prostaglandin production has an obligatory role in implantation and the concentration of prostaglandin increases at implantation sites (Kennedy, 1990; Smith, 1991; Pakrasi, 1997). The results of the present study and those of Jacobs et al. (1994) suggest that IL-1 in the endometrium induces COX-2 gene expression in the stromal cells and thereby modulates the production of prostaglandins by these cells.

Type 1 IL-1 receptors (IL-1R1) and its ligands are expressed in the endometrium during peri-implantation in rodents. In the mouse uterus, IL-1R1 protein is located in the luminal epithelium during preimplantation and its concentration increases on the day of implantation in areas surrounding the blastocyst (Simón et al., 1994). At day 7 of pregnancy in mice, after the onset of implantation, IL-1R1 protein is localized in the stromal cells in the endometrium undergoing decidualization. Therefore, in mice, IL-1R1 expression occurs in a time- and cell-dependent fashion during the peri-implantation period. IL-1 bioactivity is present in the uterus on days 3-9 of pregnancy, with the greatest activity on days 3-5 (De et al., 1993). This increase in bioactivity on days $3-5$ is accompanied by an increase in IL$1 \alpha$ and IL- $1 \beta$ mRNA in the uterus. IL- $1 \alpha$ and IL- $1 \beta$ mRNA is detectable in the uterus on days 1-8 of pseudopregnancy (Choudhuri and Wood, 1993); the concentration of both is highest on days 1-2 of pseudopregnancy, and decreases from days 3-8. However, when a deciduogenic stimulus is applied to the uterus on day 4 , there is a marked increase in the concentration of mRNA for both IL- $1 \alpha$ and IL- $1 \beta$ compared with non-stimulated uterine horns. On day 7 of pregnancy in mice, IL-1 $\alpha$ protein is not detectable in the maternal decidual cells but is detected in the embryo at the interface with these cells (Simón et al., 1994). Although IL-1R1 and its ligands are expressed in the mouse uterus during peri-implantation, their role in implantation is not clear. The results of the present study and that of Jacobs et al. (1994) show that IL-1 $\alpha$ increases COX-2 gene expression in rat and mouse endometrial stromal cells, respectively. Therefore, the IL-1R1 signalling system in the uterus during peri-implantation may have a role in modulating endometrial COX-2 gene expression and prostaglandin production.

Previous studies indicate that the IL-1R1-signalling system is not required for implantation in mice. IL-1R1deficient mice have no profound alterations in their reproduction (Abbondanzo et al., 1996). In these mice, there is a $20 \%$ decrease in litter size that is not due to an effect on implantation rate. Furthermore, when normal and IL-1R1deficient mice are injected with IL-1 receptor antagonist (which binds to IL-1R1 and competitively inhibits IL-1 $\alpha$ and IL-1 $\beta$ binding (Seckinger et al., 1987; Dripps et al., 1991; Granowitz et al., 1991)) there is no effect on implantation (Abbondanzo et al., 1996). This is contrary to the findings of Simón et al. (1994). It remains to be determined whether the concentration of prostaglandin at implantation sites in IL1R1-deficient mice is similar to that in wild-type mice.

In summary, IL- $1 \alpha$ causes an increase in steady-state concentration of COX-2 mRNA and protein in endometrial stromal cells isolated from the uteri of ovariectomized rats that have been sensitized for decidualization. The IL-1 $\alpha$ induced increase in COX-2 mRNA and protein is inhibited by dexamethasone. From these results it is concluded that increases in the amount of COX-2 mRNA and protein in response to IL-1 $\alpha$ explain, at least in part, the observation that IL-1 $\alpha$ stimulates cyclooxygenase activity and prostaglandin production in rat endometrial cells.

This work was supported by the Medical Research Council of Canada grant \#MA-10414. The human recombinant IL-1 $\alpha$ was a generous gift from the National Cancer Institute, Frederick, MD, the EcoRI digests of full-length rat cDNAs were kindly provided by $\mathrm{L}$. Feng, Scripps Research Institute, La Jolla, CA, and the 18S rRNA probe was kindly provided by G. L. Hammond, London Regional Cancer Centre, London, Ontario.

\section{References}

Abbondanzo SJ, Cullinan EB, McIntyre K, Labow MA and Stewart CL (1996) Reproduction in mice lacking a functional type 1 IL-1 receptor Endocrinology 137 3598-3601

Bany BM and Kennedy TG (1995a) IL-1 $\alpha$ regulates prostaglandin production and cyclooxygenase activity in sensitized endometrial stromal cells in vitro. Biology of Reproduction 53 126-132

Bany BM and Kennedy TG (1995b) Regulation by epidermal growth factor of prostaglandin production and cyclooxygenase activity in sensitized rat endometrial stromal cells in vitro. Journal of Reproduction and Fertility 104 57-62

Bany BM and Kennedy TG (1997) Regulation of cyclooxygenase gene expression in rat endometrial stromal cells: the role of epidermal growth factor Developmental Genetics 21 109-115

Chakraborty I, Das SK, Wang J and Dey SK (1996) Developmental expression of the cyclo-oxygenase- 1 and cyclo-oxygenase- 2 genes in the periimplantation mouse uterus and their differential regulation by the blastocyst and ovarian steroids Journal of Molecular Endocrinology 16 107-122

Chomczynski P and Sacchi N (1987) Single step method of RNA isolation by guanidium thiocyanate-phenol-chloroform extraction Analytical Biochemistry $162156-159$

Choudhuri R and Wood GW (1993) Production of interleukin-1, interleukin-6, and tumor necrosis factor alpha in the uterus of pseudopregnant mice Biology of Reproduction $49596-603$

De M, Sanford TR and Wood GW (1993) Expression of interleukin 1, interleukin 6 and tumor necrosis factor $\alpha$ in mouse uterus during the periimplantation period of pregnancy Journal of Reproduction and Fertility 97 83-89

DeWitt DL (1991) Prostaglandin endoperoxide synthase: regulation of enzyme expression Biochimica and Biophysica Acta 1083 121-134

DeWitt DL, Kraemer SA and Meade EA (1991) Serum induction and superinduction of PGG/H synthase mRNA levels in $3 \mathrm{~T} 3$ fibroblasts. In Prostaglandins and Related Compounds II pp 75-90 Ed. B Samuelsson. Raven Press, New York

Dripps DJ, Brandhuber BJ, Thompson RC and Eisenberg SP (1991) Interleukin-1 (IL-1) receptor antagonist binds to the $80-\mathrm{kDa}$ IL-1 receptor but does not initiate IL-1 signal transduction Journal of Biological Chemistry 266 10331-10336 
Egan RW, Paxton J and Kuehl FA (1976) Mechanism of irreversible selfdeactivation of prostaglandin synthase Journal of Biological Chemistry 251 7329-7335

Feng L, Sun W, Xia Y, Tang WW, Chanmugam P, Soyoola E, Wilson CB and Hwang D (1993) Cloning of two isoforms of rat cyclooxygenase: differential regulation of their expression Archives of Biochemistry and Biophysics $\mathbf{3 0 7}$ 361-368

Granowitz EV, Clark BD, Mancilla J and Dinarello CA (1991) Interleukin-1 receptor antagonist competitively inhibits the binding of interleukin-1 to the type II interleukin-1 receptor Journal of Biological Chemistry 266 14 147-14 150

Herschman HR (1994) Regulation of prostaglandin synthase-1 and prostaglandin synthase-2 Cancer Metastasis Reviews 13 241-246

Hla T and Neilson K (1992) Human cyclooxygenase-2 cDNA Proceedings National Academy of Sciences USA 89 7384-7388

Jacobs AL and Carson DD (1993) Uterine epithelial cell secretion of interleukin- $1 \alpha$ induces prostaglandin $\mathrm{E}_{2}\left(\mathrm{PGE}_{2}\right)$ and $\mathrm{PGF}_{2 \alpha}$ secretion by uterine stromal cells in vitro. Endocrinology 132 300-308

Jacobs AL, Hwang D, Julian J and Carson DD (1994) Regulated expression of prostaglandin endoperoxide synthase- 2 by uterine stroma Endocrinology 135 1807-1815

Kennard EA, Zimmerman PD, Friedman CI and Kniss DA (1995) Interleukin-1 $\beta$ induces cyclooxygenase- 2 in cultured human decidual cells American Journal of Reproductive Immunology 34 65-71

Kennedy TG (1990) Eicosanoids and blastocyst implantation. In Eicosanoids and Reproduction pp 123-138 Ed. MD Mitchell. CRC Press, Boca Raton, FL

Kujubu DA, Fletcher BS, Varnum BC, Lim RW and Herchman HR (1991) TIS10, a phorbol ester tumor promotor-inducible mRNA from Swiss-3T3 cells, encodes a novel prostaglandin synthase/cyclooxygenase homologue Journal of Biological Chemistry $26612866-12872$

Laemmli UK (1970) Cleavage of structural proteins during the assembly of the head of bacteriophage T4 Nature $227680-685$

Langenbach R, Morham SG, Tiano HF, Loftin CD, Ghanayem BI, Chulada PC, Mahler JF, Lee CA, Goulding EH, Kluckman KD, Kim HS and Smithies O (1995) Prostaglandin synthase 1 gene disruption in mice reduces arachidonic acid-induced inflammation and indomethacininduced gastric ulceration Cell 83 483-492

Lim H, Paria BC, Das SK, Dinchuk JE, Langenbach R, Trzaskos JM and Dey SK (1997) Multiple female reproductive failures in cyclooxygenasedeficient mice Cell 91 197-208

McCormick SA and Glasser SR (1980) Differential response of individual uterine cell types from immature rats treated with estradiol Endocrinology 106 1634-1649

Merlie JP, Fagan D, Mudd J and Needleman P (1988) Isolation and characterization of the complementary DNA for sheep seminal vescicle prostaglandin endoperoxide synthase (cyclooxygenase) Journal of Biological Chemistry 263 3550-3553

O'Banion MK, Winn VD and Young DA (1992) cDNA cloning and functional activity of a glucocorticoid-regulated inflammatory cyclooxygenase Proceedings National Academy of Sciences USA 89 4888-4892

Pakrasi PL (1997) Prostaglandins and ovum implantation in mice Prostaglandins 278 53-57

Porreca E, Reale M, Di Febbo C, Di Gioacchino M, Barbacane RC, Castellani ML, Baccante G, Conti P and Cuccurullo F (1996) Down-regulation of cyclooxygenase- 2 (COX-2) by interleukin-1 receptor antagonist in human monocytes Immunology 89 424-429

Rzymkiewicz D, Leingang K, Baird N and Morrison AR (1994) Regulation of prostaglandin endoperoxide synthase gene expression in rat mesangial cells by interleukin-1 $\beta$ American Journal of Physiology 266 F39-F45

Sambrook K, Fritsch EF and Maniatis T (1989) Molecular Cloning: A Laboratory Manual 2nd Edn Cold Spring Harbor Laboratory Press, Cold Spring Harbor, New York

Seckinger P, Lowenthal JW, Williamson K, Dayer J-M and MacDonald HR (1987) A urine inhibitor of interleukin 1 activity that blocks ligand binding Journal of Immunology 139 1546-1549

Shaw G and Kamen R (1986) A conserved AU sequence from the 3 untranslated region of GM-CSF mRNA mediates selective mRNA degradation Cell 46 659-667

Simón C, Frances A, Piquette GN, Danasouri IE, Zurawski G, Dang W and Polan ML (1994) Embryonic implantation in mice is blocked by interleukin1 receptor antagonist Endocrinology 134 521-528

Smith CL and Hammond GL (1991) Ontogeny of corticosteroid-binding globulin biosynthesis in the rat Endocrinology 128 983-988

Smith SK (1991) The role of prostaglandins in implantation Baillière's Clinical Obstetrics and Gynaecology 5 73-94

Smith WL, Marnett LJ and DeWitt DL (1991) Prostaglandin and thromboxane biosynthesis Pharmacology and Therapeutics 49 153-179

Takahashi Y, Ueda N, Yoshimoto T, Yamamoto S, Yokoyama C, Miyata A, Tnabe T, Fuse I, Hattori A and Shibata A (1992) Immunoaffinity purification and cDNA cloning of human prostaglandin endoperoxide synthase (cyclooxygenase) Biochemical and Biophysical Research Communications $182433-438$

Towbin H, Staehlin T and Gordon J (1979) Electrophoretic transfer of proteins from polyacrylamide gels to nitrocellulose sheets: procedures and some applications Proceedings National Academy of Sciences USA 76 4350-4354

Viganò T, Habib A, Hernandez A, Bonazzi A, Boraschi D, Lebret M, Cassina E, Maclouf J, Sala A and Folco G (1997) Cyclooxygenase-2 and synthesis of $\mathrm{PGE}_{2}$ in human bronchial smooth-muscle cells American Journal of Respiratory and Critical Care Medicine 155 864-868

Yucel-Lindberg T, Ahola $\mathbf{H}$, Nilsson S, Carlstedt-Duke $J$ and Modéer $T$ (1995) Interleukin-1 $\beta$ induces expression of cyclooxygenase-2 mRNA in human gingival fibroblasts Inflammation 19 549-560

Zhang V, O'Sullivan M, Hussain H, Roswit WT and Holtzman MJ (1996) Molecular cloning, functional expression, and selective regulation of ovine prostaglandin $\mathrm{H}$ synthase-2 Biochemical and Biophysical Research Communications 227 499-506 